\title{
ANALYSIS OF THE RELATIONSHIP BETWEEN E-SERVICE QUALITY, CUSTOMER SATISFACTION, AND CONSUMER BEHAVIORAL INTENTIONS: A CASE STUDY OF ONLINE-BASED AGRIBUSINESS COMPANIES IN MALANG CITY
}

\author{
Intan Dian Retno*, Student \\ Setiawan Budi, Shinta Agustina, Lecturers \\ Master's Program, Faculty of Agriculture, Brawijaya University, Malang, Indonesia \\ ${ }^{*}$ E-mail: dianretnointan@gmail.com
}

\begin{abstract}
The trend of internet uses in daily activities causes changes in the way business and society work. Business owners are now competing to offer better products and switch to online transactions. This intense competition causes marketers to find ways to be able to compete. In terms of e-commerce, the quality of service is the main factor of a successful e-business. The purpose of this study is to analyze the relationship between e-service quality, customer satisfaction, and consumer behavioral intentions. The data was obtained from 41 online shop consumers through an online survey using structural equation modeling (SEM). The results showed that positive evaluation of e-service quality will positively impact customer satisfaction and behavioral intention. Customer satisfaction also has a positive impact on consumer behavioral intention. This study suggests that practitioners use the model to allocate resources to essential quality attributes, or those that are low-performance, which is needed to improve customer satisfaction and positive consumer behavioral intentions.
\end{abstract}

\section{KEY WORDS}

E-service quality, e-satisfaction, behavioral intention, online shop.

Nowadays, the trend of internet usage through mobile devices is increasing and modern societies' lives are integrated with smartphones (Hamdani, 2016). This is a result of the digital revolution that has been taking place over the past half century. The digital revolution also greatly affects the way business and society work. Conventional industries are slowly being replaced by digital-based industries. The physical units of business has now being replaced by websites and applications. This shows that in this new digital environment, the use of websites and applications is important to build company's reputation which could influence consumer buying behavior. Conventional companies are now starting to offer and conduct online transactions (e-commerce).

Electronic commerce is currently growing very rapidly. This can be seen from the large number of Indonesia e-commerce transactions that continue to increase each year. From 2013 to 2017, the increase reached more than 50 percent (Databoks, Katadata Indonesia (2017)). This trend is now in demand because online purchase decision-making process is not as complex as the process done offline. Consumers get the benefits of e-commerce such as finding the exact products that they want to buy, comparing prices, the ease to obtain domestic and foreign products, the quality of the product that are as good as the ones in offline stores, and so on.

However, online transactions have shortcomings that will affect the implementation process. Transaction processes that are not supported by sufficient receipts can lead to scams and fraud, especially when the buyers and sellers do not know each other. There is a high risk of fraud in online transactions, such as unilateral cancellations, items not being sent, refunds, misleading information, and dispute resolution. Apart from these advantages and disadvantages, online businesses continue to grow rapidly despite all the risks.

Many researches have been done to find the determinants of the success of these $e-$ commerce based companies. One of them was done by Lee and Lin (2005) which stated that the main determinant of the success and failure of e-commerce based companies not only lies on the presence of company websites and low prices, but also the service quality. 
Delivering service quality means being consistent with customers' expectations. This is an important strategy for marketers to be standout with great services they offer by setting standards and satisfying customer's needs.

Companies will try to increase consumer demand for goods and services offered. Thus, producers need to understand what elements of shopping experience are very important for customer satisfaction and potential consumers. Previous studies showed that perceptions of service quality lead to customer's satisfaction, which will lead to beneficial behavioral intentions. This study aims to study these relationships and provide a more comprehensive understanding of phenomena that are relevant to academics and practitioners. Therefore, the research questions of this study can be stated as follows:

- What is the relationship between e-service quality and customer satisfaction?

- What is the relationship between customer satisfaction and consumer behavior intentions?

- What is the relationship between e-service quality and consumer behavioral intentions?

The purposes of this study are:

- To analyze the relationship between e-service quality and customer satisfaction;

- To analyze the relationship of satisfaction and consumer behavior intentions;

- To analyze the relationship of e-service quality and consumer behavioral intentions.

\section{CONCEPTUAL FRAMEWORK AND HYPOTHESES}

The conceptual framework in this study is shown in Figure 1. This model displays the second order construct measurements of e-service quality through dimension processing, outcome, and recovery. In addition, Figure 1 also shows the hypotheses of the relationship between e-service quality, customer satisfaction and consumer behavioral intentions. The definition of e-service quality was first defined by Zeithaml, Parasuraman, and Malhotra (2002) as the extent of websites in facilitating e-commerce transactions and delivering products and services efficiently.

Collier and Bienstok (2006) measured perceived e-service quality using 3 dimensions based on the unique characteristics of service quality perceptions in online settings: process dimensions (based on interactive processes that take place online), results (results of how the product or service are delivered), and recovery (the way service failure is being handled), to increase the understanding of how customers evaluate the quality of e-services.

The interactive process and quality dimensions that occur between consumers and websites are represented by five dimensions: privacy, design, information accuracy, ease of use, and functionality. The result dimension has other dimensions for measurement, namely order timeliness, order accuracy, and order conditions. The recovery dimension in e-service has three other dimensions, namely interactive fairness, procedural fairness, and outcome fairness.

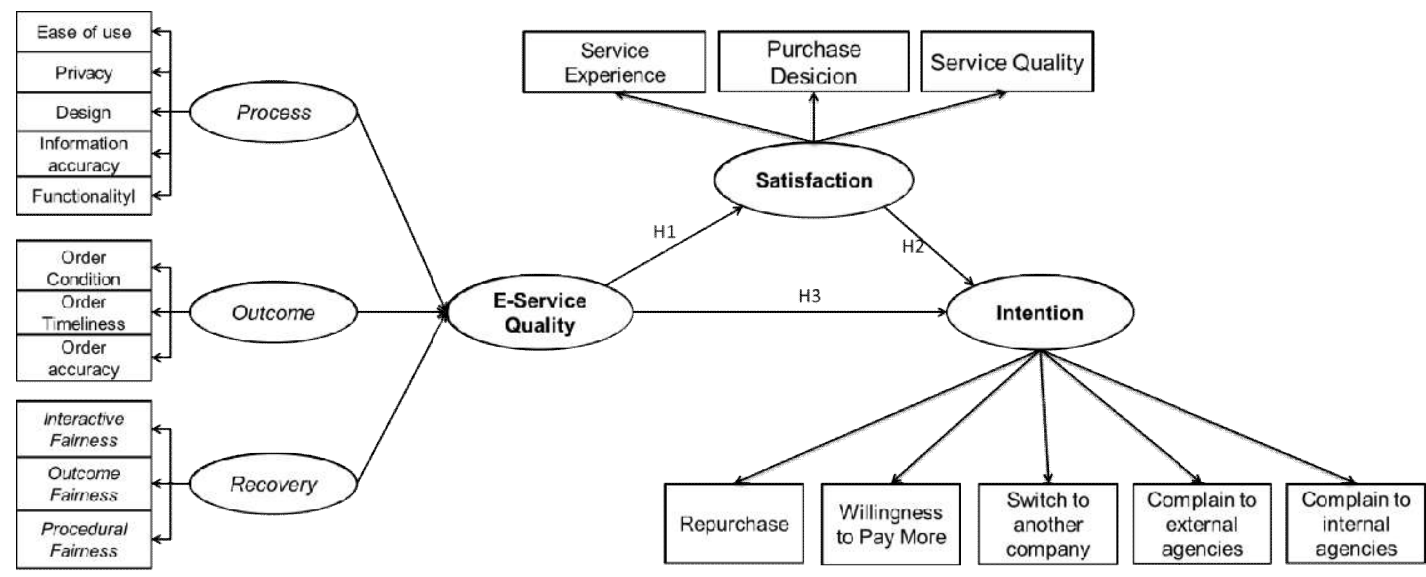

Figure 1 - Conceptual Framework 
The model of service encounter evaluation by Bitner (1990) showed a very close relationship between meeting service satisfaction and perceived service quality. The attitude and behavior of employees affect the perceived service performance. In an online context, Szymanski and Hise (2000) defined e-satisfaction as a cumulative effect from a series of customer experiences with service providers in a given time. In line with these opinions, Anderson and Srinivasan (2003) stated that e-satisfaction relates to customer purchase experience in certain e-commerce companies. Previous researches have concluded that customer satisfaction is driven by various quality attributes (Collier and Bienstock, 2006; Cristobal et al., 2007; Gounaris, 2010; Szymanski and Hise, 2000). That means, how the services are provided is important to improve customer satisfaction. Finally, positive (or negative) consumer perceptions of e-service quality will result in satisfaction (or dissatisfaction).

In the context of conventional market in various services, previous researches has found a significant positive relationship between perceived service quality and consumer behavior (eg Carlson and O'Cass, 2010; Cronin et al., 2000; Parasuraman et al., 1988; Zeithaml et al., 1996). Meanwhile in the context of electronic environment, perceived eservice quality has the potential to increase behavioral intentions such as reviewing websites, increasing site visits, buying intentions and positive recommendations, which can maximize the advantage of e-commerce (Santos, 2003). The intention of consumer behavior referred in this study was analyzed by measuring the intention to repurchase, the desire to pay more, the desire to move, and complaints delivered to the company. This perceived positive e-service quality can later be seen on the relationship between e-service quality and consumer behavioral intentions. If the consumer's evaluation of e-service quality is positive, then consumers will show a tendency to repurchase, pay more, and reluctant to move or make complaints to the company. On the contrary, if the consumer's evaluation of e-service quality is negative, consumers will tend to stop buying, move to other competitors, and make complaints outside the company (negative word-of-mouth).

Previous studies on service quality, both conventional and internet-based service, indicated that satisfaction has a strong positive relationship with consumer positive behavioral intentions (Carlson and O'Cass, 2010; Collier and Bienstock, 2006; Cristobal et al., 2007). On the contrary, dissatisfied consumers will find alternative websites and be easily lured into competitor's website, avoid website approach, and reduce the dependency on the website (Anderson and Srivinasan, 2003). In the same context, it can be concluded that consumers who are satisfied with the delivery of e-service experience (through various quality dimensions of a website) will tend to show positive behavioral intentions.

The hypotheses can be formulated based on the framework above as follows:

- There is a positive relationship between perceived e-service quality and customer satisfaction;

- There is a positive relationship of satisfaction consumers of consumer behavior intentions;

- There is a positive relationship between perceived e-service quality and behavioral intentions.

\section{METHODS OF RESEARCH}

The location of the research is chosen based on phenomena or problems in accordance with the research objectives. The research was conducted in an online shop in Malang established in 2017 which provides vegetables. The samples were obtained using non-probability sampling with convenience sampling technique. Convenient sampling is a type of non-probability sampling method in which samples are taken from a group of people who are easy to reach (Wrenn et al., 2002). The method was chosen to collect the data based on the findings found in previous research on e-service quality and website effectiveness that the approach convenience sampling is an efficient and acceptable sampling method for adoption. (Gummerus, 2004; Carlson, 2010). There were 41 respondents in this study. According to the rule of thumb by Roscoe (1975) in Sugiyono 
(2012), this number has fulfilled the minimum sample in a research, so that data analysis can be done.

The data was obtained using online questionnaire and observation. The questionnaire, which contained several closed questions, were distributed online through a website. The answers were in form of Likert Scale with five categories: strongly disagree to strongly agree $(1$ - 5). The validity and reliability of the data were tested using PLS (Partial Least Square) before being analyzed to find the relationship between the constructs.

This study uses PLS as an analytical tool with several considerations, including how PLS making no assumptions on distribution, being able to estimate complex models when using small sample sizes and not requiring interval scale measurements. Furthermore, PLS is not obstructed by collinearity between manifest variables. Chin (1998) states that the minimum sample size required for covariance-based techniques (e.g. AMOS and LISREL) is 200, while in PLS, the minimum sample size ranges from 30 to 100. Therefore, the sample size of this study met the required amount to use PLS.

\section{RESULTS AND DISCUSSION}

\section{Evaluation of Measurement Model:}

Outer Model. The testing of validity was done using analysis convergent validity and discriminant validity, while the reliability test is seen from the composite reliability and Cronbach's alpha. Table 1 shows the results of the test Convergent validity $1^{\text {st }}$ where all the indicators in the research are valid, as Chin (1995) stated that the rule of thumb for convergent validity is $>0.7$. Besides convergent validity, indicator validity can also be measured using discriminant validity, where the test results are shown in Table 2. The discriminant validity was calculated using a cross correlation with the criterion: if the value loading factor in a corresponding variable is greater than the indicator correlation value on the other variables, then the indicator is declared valid in measuring the corresponding variable. Therefore, it could be concluded that each indicator is valid in measuring each variable.

Table 3 - Validity Test Results of $2^{\text {nd }}$ Order Formative Model

\begin{tabular}{|c|c|c|c|c|}
\hline Variables & Dimensions & Weight & SE & P value \\
\hline \multirow{2}{*}{ Perceived E-Service Quality } & Process & 0.348 & 0.135 & 0.007 \\
\cline { 2 - 5 } & Outcome & 0.343 & 0.135 & 0.008 \\
\cline { 2 - 5 } & Recovery & 0.349 & 0.135 & 0.007 \\
\hline
\end{tabular}

Source: WarpPLS5.0, 2018 data (processed).

Unlike the reflective indicators, formative indicators are not correlated. Instead, they compare weights (weight) of each indicator so that which indicators contribute most to the construct can be determined. Based on the results of the validity test above, the value of $p<\alpha=5 \%$, therefore, the three dimensions in perceived e-service quality are valid.

Table 4 - Test Results

\begin{tabular}{|c|c|c|c|}
\hline Variable & Dimension & Composite Reliability & Cronbach's Alpha \\
\hline \multirow{3}{*}{ Perceived e-service quality } & Process & 0.970 & 0.961 \\
\cline { 2 - 3 } & Outcome & 0.952 & 0.924 \\
\cline { 2 - 3 } & Recovery & 0.974 & 0.959 \\
\hline \multicolumn{2}{|c|}{ Customer satisfaction } & 0.974 & 0.960 \\
\hline \multicolumn{2}{|c|}{ Consumer behavior intention } & 0.922 & 0.894 \\
\hline
\end{tabular}

Source: WarpPLS5.0, 2018 data (processed).

Based on the table above, the composite reliability values in the dimension process, outcome, recovery, customer satisfaction and consumer behavior intention are greater than 0.7. Based on the calculations of all composite reliability indicators that measure these dimensions, they are declared reliable. Furthermore, the value of Cronbach's Alpha on the 
dimensions of the process, outcome, recovery, customer satisfaction and dimensions of consumer behavior intention is greater than 0.6. Thus, all the indicators that measure these dimensions are declared reliable.

Inner Model. The evaluation of the inner models was done using $\mathrm{R}^{2}$ and $\mathrm{Q}^{2}$. The results of the inner models evaluation are as follows:

Table 5 - Evaluation Results of Inner Models

\begin{tabular}{|c|c|c|}
\hline Endogen & R-Square & Q-Square \\
\hline Customer satisfaction & 0.203 & 0.200 \\
\hline Consumer behavioral intention & 0.283 & 0.321 \\
\hline
\end{tabular}

Source: WarpPLS5.0, 2018 data (processed).

The results above indicate that the diversity of customer satisfaction variables can be explained by perceived e-service quality of $20.3 \%$ with the ability strong predictions $\left(Q^{2}>0\right)$. The diversity of consumer behavioral intentions can be explained by perceived e-service quality and customer satisfaction by $28.3 \%$ with strong predictive abilities.

Hypothesis Testing:

The testing criteria state that if the path coefficient is positive and the $p$ value $<$ level of significance (Alpha $(\alpha=5 \%)$ ), then there is a positive and significant relationship between exogenous and endogenous variables. The results of the hypothesis testing can be found in the following figure:

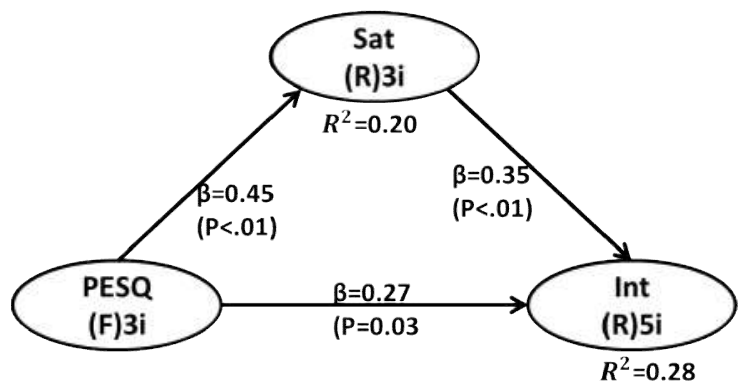

Figure 2 - Inner Model

Perceived e-Service Quality Has a Positive Relationship with Customer satisfaction. The relationship of perceived e-service quality to customer satisfaction produces a path coefficient of 0.451 with a $P$ Value of $<0.001$. The test results show that the path coefficient is positive and $p$ value < level of significance (Alpha $(\alpha=5 \%)$ ). This shows that there is a positive and significant relationship between perceived e-service quality and customer satisfaction. These results indicate that the more positive the perceived e-service quality, the more the customer satisfaction will increase.

E-service quality has been treated as a reliable tool to obtain a sustainable competitive advantage, which means that aspects of service quality process a substantial strategic role for the organization. When online stores are rapidly growing, their service qualities has become an important factor in determining the success or failure of them by affecting consumers' online shopping experiences (Yang, 2001 in Rahman and Miazee, 2010). If an online-based company wants to succeed, all the aspects of its services must be tightly integrated in terms of systems, networks, procurements, shipping, and customer supports. The key element of business achievement is quality (Dale, 1999 in Rahman and Miazee, 2010). Without a quality management approach, it is guaranteed that the quality of the system, its staff and suppliers will not be able to provide the right level of service to satisfy its customers.

Customer Satisfaction has a Positive Relationship with Consumer Behavioral Intentions. The relationship between customer satisfaction and consumer behavior intentions produces a path coefficient of 0.352 with $P$ Value of $<0.01$. The test results show that the 
path coefficient is positive and $p$ value < level of significance (Alpha $\alpha=5 \%$ ). This shows that there is a positive and significant relationship between customer satisfaction and consumer behavioral intentions. This means that the more positive consumer perceptions of satisfaction tend to increase consumer behavioral intentions.

Similarly, the results of Udo's research (2010) showed that there is a strong positive relationship between satisfaction and consumer behavioral intentions, in form of intention to use e-service regularly, the intention to use electronic services, and the intention to use eservice in the future. The research conducted by Sivadas (2000) showed that satisfaction relates to relative attitudes, repurchases, and recommendations. This attitude could benefit the seller in attracting new customers. However, consumers will have a positive attitude if the seller could satisfy them and improve the quality of the service. The intention of beneficial behavior in this study is represented by repurchase, desire to pay more, desire to move, as well as indirect and direct complaints to the organization.

Perceived e-Service Quality has a Positive Relationship with the Consumer Behavioral Intentions. The relationship between perceived e-service quality and consumer behavioral intentions produces a path coefficient of 0.270 with $p$ value of $<0.01$. The test results show that the path coefficient is positive and $p$ value < level of significance (Alpha $(\alpha=5 \%)$ ). This shows that there is a positive and significant relationship between perceived e-service quality and consumer behavior intentions. This means that higher perceived e-service quality tends to increase consumer behavioral intentions.

Previous e-retail studies have found that there is a direct relationship between eservice quality and various behavioral intentions. Researchers have found that e-service quality is positively correlated with purchase intentions and site visits (Collier and Bienstock, 2006; Cristobal et al., 2007; Loiacono et al., 2002), the possibility of recommending websites to others (Collier and Bienstock, 2006) and leads to a reduction in complaint behavior (Janda et al., 2002). In correlation to this study, where good e-service quality is positively correlated with repurchase intention and the desire to pay more. This will lessen the desire to move to other online shops and make complaints outside the organization. Complaining directly to the organization is highly recommended. Consumers who make direct complaints to the organization indicate that they are giving the seller a second chance to improve the quality of their service.

Satisfaction as a Mediation between e-Service Quality and Behavior Intention. The testing of indirect effects was used to correlate exogenous variables and endogenous variables through mediating variables. In this study, the variable that allows mediation is the satisfaction variable. This satisfaction variable mediates the exogenous variable (perceived e-service quality) to behavioral intentions. The test criteria states that if $p$ value $<$ the level of significance (Alpha $(\alpha=5 \%)$ ), then there is a significant relationship between exogenous variables and endogenous variables through mediating variables. In other words, mediating variables can significantly mediate between exogenous variables and endogenous variables. The results show that the relationship between perceived e-service quality and consumer behavior intentions through customer satisfaction produces a p-value of 0.066 (weakly significant). The relationship coefficient between of perceived e-service quality and consumer behavior intentions through customer satisfaction is 0.159 . This means perceived e-service quality is positively and significantly related to consumer behavior intentions through customer satisfaction. This means higher customer satisfaction caused by better perceived e-service quality will have a positive impact on consumer behavioral intentions with low significance. These results support the research of Kumar et. al (2013) and Soelasih (2017) which stated that satisfaction alone is not enough to shape consumer loyalty. Soelasih (2017) categorizes these consumers into shifting loyals, where based on the descriptive data, these respondents stated that they are satisfied, but their satisfaction does not cause too much desire to buy more products. They are also still unwilling to pay more and considering moving. 


\section{CONCLUSION AND SUGGESTIONS}

Based on the results of this study, several things can be concluded and used as implications for practitioners in implementing e-service quality. First, e-service quality has a positive and significant relationship with customer satisfaction. Based on the descriptive analysis results of the e-service quality after evaluating the dimensions of the process, outcome, and recovery, the respondents agreed that e-service quality of Online Shop X is good. Respondents also agreed that they were satisfied with the services provided by Online Shop $X$. This positive relationship between e-service quality and customer satisfaction showed that if consumer perceptions of e-service quality are good, it would have a positive impact on customer satisfaction. The dimensions that contribute the most to form e-service quality are the dimensions of recovery, where indicators that influence consumer evaluation the most are the indicators of the fairness outcome. These results showed the marketers that there needs to be clear provisions and guidance in providing compensation to consumers. The compensations given can be in the form of apologies, discounts, giving out free products or replacements. These clear guidelines or provisions will be useful for managers in handling service failures as well as guaranteeing consumers that a service failure will be compensated by the company.

Secondly, e-service quality has a positive and significant relationship to consumer behavioral intentions. The results of the descriptive analysis show that respondents have a good perception of e-service quality and positive behavioral intentions. A positive and significant relationship between e-service quality and consumer behavioral intention indicates that if consumer perceptions of e-service quality are good, it will have a positive impact on consumer behavioral intentions. The consumer behavioral intentions is mostly reflected by the behavioral complaints outside the organization, where consumers are hesitant or neutral to complain outside the organization. This indicates that there is a possibility that consumers will make complaints outside the organization or also known as negative word-of-mouth. To anticipate this, managers and marketers must create an application or evaluation system of services to maintain communication with the customers, to get feedbacks on services that have been provided, and to facilitate consumers in making complaints when there is a service failure. Therefore, when something goes wrong, the company is the first party to know, or if it's possible the only one who knows, about the service failures.

Lastly, customer satisfaction has a positive and significant relationship with behavioral intentions. The descriptive analysis results show that consumers are satisfied with the services provided by Online Shop $X$ and have positive behavioral intentions. The positive relationship between customer satisfaction and consumer behavioral intention indicates that increasing customer satisfaction will have a positive impact on consumer behavioral intentions. It will be beneficial to the sellers if they are able to satisfy their customers. In addition, satisfaction is a mediating variable that strengthens the relationship between eservice quality and consumer behavioral intentions. These results need to be considered by managers and marketers so that they will be able to implement strategies that focus on increasing customer satisfaction and to build long-term relationships with the customers. There are ways to accomplish those goals: by placing consumers as a priority, being responsive to consumers, and being reliable in fulfilling the needs and desires of consumers.

\section{REFERENCES}

1. Anderson, R. and Srinivasan, S. 2003. E-satisfaction and e-loyalty: a contingency framework. Psychology \& Marketing. Vol. 20 No. 2. Hal $123-138$.

2. Bitner, M J. 1990. Evaluating Service Encounters: The Effects of Physical Surrounding and Employee Responses. Journal of Marketing. Vol. 54 No. 2. Hal $69-82$.

3. Carlson J. dan O'Cass A. 2010. Exploring The Relationships Between E-Service Quality, Satisfaction, Attitudes and Behaviours In Content-Driven E-Service Web Sites. Journal of Services Marketing. Vo.I 24 No. 2. Hal $112-127$. 
4. Chin, W. 1998. The Partial Least Squares Approach for Structural Equation Modelling. in Marcoulides, G. (Ed.). Modern Methods for Business Research. Laurence Erlbaum Associates. Mahwah. NJ. Hal. $295-336$.

5. Collier, J. and Bienstock, C. 2006. Measuring service quality in e-retailing. Journal of Service Research. Vol. 8 No. 3. Hal $260-275$.

6. Cristobal, E., Flavian, C. and Guinaliu, M. (2007). Perceived E-Service Quality (Pesq): Measurement Validation and Effects on Customer satisfaction and Web Site Loyalty. Managing Service Quality. Vol. 17 No. 3. Hal $317-340$.

7. Cronin, J., Brady, M., Thomas, G. and Hult, M. 2000. Assessing the effects of quality, value and customer satisfaction on consumer behavioural intentions in service environments. Journal of Retailing. Vol. 76 No. 2. Hal $193-221$.

8. Gounaris, S., S. Dimitriadis., V. Statakopoulos. 2010. An Examination of The Effects of Service Quality and Satisfaction on Customers' Behavioral Intentions in E-Shopping. Journal of Service Marketing. Vol 24 No 2. Hal 142 - 156.

9. Hamdani, Y. 2016. Revolusi Asuransi Digital. Jakarta. PT Elex Media Komputindo

10. Katadata. 2016. Transaksi E-Commerce Indonesia Naik $500 \%$ dalam 5 Tahun (online). https://databoks.katadata.co.id/datapublish/2016/11/16/transaksi-e-commerce-indonesianaik-500-dalam-5-tahun. Diakses 25 Januari 2018

11. Kumar,V.; Pozza, Ilaria Dalla; Ganesh, Jaishankar. (2013) "Revisiting the SatisfactionLoyalty Relationship: Empirical Generalizations and Directions for Future Research". Journal of Retailing (89), 246-262

12. Lee, G. dan Lin, H. 2005. Customer Perceptions of E-Service Quality in Online Shopping. International Journal of Retail \& Distribution Management. Vol. 33 No. 2. Hal $161-76$.

13. Rahman, M dan H. Miazee. 2010. E-Service Quality and Customer Satisfaction: A Study of Online Customers in Bangladesh. Master Thesis. Department of Social Sience. Sweden University.

14. Santos, J. 2003. E-Service Quality: A Model of Virtual Service Quality Dimensions. Managing Service Quality. Vol. 13 No. 3. Hal 233 - 246.

15. Soelasih, Y. 2017. Kepuasan Konsumen Tidak Selalu Membentuk Loyalitas. Jurnal Manajemen. Volume XXI, No. 03, Oktober 2017: 363-380.

16. Sugiyono. 2012. Metode Penelitian Bisnis: Pendekatan Kuantitatif, Kualitatif, dan R\&D. Bandung. Penerbit Alfabeta.

17. Szymanski, D.M. dan Hise, R.T. 2000. E-Satisfaction: An Initial Examination. Journal of Retailing. Vol. 76 No. 3. Hal $309-322$.

18. Udo, G J., K K Bagchi., dan P J Kirs. 2010. An Assessment of Customers' E-Service Quality Perception, Satisfaction and Intention. International Journal of Information Management. Vol 30. Hal $481-492$

19. Wrenn, B., W B Wrenn, D L Loudon, dan R E Stevens. 2002. Marketing Research : Text and Cases. New York. Best Business Book.

20. Zeithaml V, Berry L, dan Parasuraman A. The behavioral consequences of service quality. Journal of Marketing. Vol 60 No 2. Pp. 31-46.

21. Zeithaml, V.A., Parasuraman, A. dan Malhotra, A. 2002. Service Quality Delivery Through Web Sites: A Critical Review of Extant Knowledge. Journal of the Academy of Marketing Science. Vol. 30 No. 4. Hal $362-375$. 